\title{
Strategies to promote sustainable behaviour in relation to water use: ideas and classifications
}

\author{
Oliveira, Luis ${ }^{1, a}$, Pereira, Andrea Franco ${ }^{2}$ and Bergamo, Marilia Lyra ${ }^{3}$ \\ ${ }^{1}$ L.Oliveira@warwick.ac.uk - University of Warwick, WMG, Coventry, CV4 7AL - United Kingdom \\ ${ }^{2}$ Universidade Federal de Minas Gerais, Escola de Arquitetura, Belo Horizonte - MG, Brasil \\ ${ }^{3}$ Universidade Federal de Minas Gerais, Escola de Belas Artes, Belo Horizonte - MG, Brasil
}

\begin{abstract}
The design of products, services and spaces can influence what we think and do, and there is the potential for using design to promote sustainable behaviours. Most examples of behaviour change interventions have as setting Western and developed countries. Environmental damage affects people in diverse parts of the globe, and recently severe droughts caused water shortage in the most populous areas in Brazil. This paper reports on workshops conducted with Brazilian students as a way to foster the generation of ideas and development of strategies to promote sustainable behaviours regarding water use, and therefore reduce consumption and waste. The ideas proposed during these workshops were classified according to established models of design for behaviour change and sustainable behaviour, indicating the categories of the most frequent suggestions. Results demonstrated how the idea generation sessions were capable of producing interesting solutions reduce consumption that could help to tackle the problem of water shortage. However, the short duration of these exercises meant that suggestions were limited in terms of scope and evaluation of impact. This paper indicates that design for behaviour change should be incorporated into regular curricula in Brazil in order to make future professionals and practitioners more familiar with these techniques and therefore more able to tackle their local and global environmental challenges.
\end{abstract}

Keywords. Sustainable design, design for behaviour change, design with intent, interventions, persuasive technology.

\section{Introduction}

Sustainability can be defined as having a world "in which humans can survive without jeopardizing the continued survival of future generations of humans in a healthy environment" (BROWN et al., 1987, p. 717). The original principle of sustainability grew from economic considerations, when humans faced serious environmental challenges. Sustainability today extends its focus from a challenge limited in space and time to become a worldwide and long-term problem (ZINK, 2008). The challenges to promote sustainability are remarkable considering that the negative environmental consequences of human behaviours are difficult to visualize due to the geographical and temporal displacement of the effects (which may occur sometime in the future and in remote places on the planet). More recently, sustainability gained momentum thanks to Non-Governmental Organizations and increased awareness of consequences of resources usage. It encompasses issues such as trade justice, anti-globalization, activism, need for more legislation and corporate social responsibility (BHAMRA; LOFTHOUSE, 2007). However, given the scale of the problem, achieving sustainability seems a daunting task. Difficulties are found in individual, societal and global scales in the attempt to tackle a problem that humans themselves caused. These challenges indicate the need for the development of innovative strategies, even if small scale, domain-specific, to somehow reduce the impact that humans cause in the environment.

In Brazil, the south-eastern region experienced severe droughts in the years of 2014 and 2015 (NOBRE et al., 2016). This issue motivated a range of strategies to try to contain consumption, from public policy, prices or user-led initiatives. Similarly to other natural resources such as air quality or global temperatures, people need to find ways to preserve fresh water supply to achieve a sustainable future.

In the attempt to reduce impacts in the environment, there are two main actions that can be performed, namely changing the infrastructure or changing behaviours (ATTARI et al., 2010). To change the infrastructure, for example replacing appliance with modern, more efficient ones, can be an easy fix for some situations. Modern products can be more sustainable, especially if designed

${ }^{a}$ Corresponding author: L.Oliveira@warwick.ac.uk 
considering their whole life cycle (PEREIRA; SOARES, 2016). In some cases, owning efficient appliances or living in energy efficient homes is not a guarantee of efficiency (GILL et al., 2010), and there are diverse challenges to the introduction of new technologies (OLIVEIRA et al., 2015). Studies have demonstrated that user behaviours vary enormously, indicating that there is scope for reduction in consumption exclusively through behaviour change (OLIVEIRA; MITCHELL; BADNI, 2012). One study on washing up methods showed that people behave in diverse ways, and on average use more detergent, water, energy and time than a regular dishwasher, and the plates are usually less clean when people do the dishes by hand (BERKHOLZ et al., 2010). But when a set of 'best practice tips' were given to consumers as instructions, they "used around 60\% less water, $70 \%$ less energy and 30\% less detergent compared with the average everyday behaviour the other subjects used. Additionally, they achieved a slightly better cleaning result" (FUSS et al., 2011). Cultural differences showed to be an important factor on user behaviours for dish washing, influencing water and detergent usage (ELIZONDO; LOFTHOUSE; BHAMRA, 2011). Laundry and dish washing energy use was reported to be highly influenced by lifestyles, and "results show a variation of a factor of five between a more sustainable and a more careless behaviour" (STAMMINGER, 2011).

In the example of water consumption, it is possible to replace the taps so there is less water flow, or we can implement strategies that make people use less water. These strategies may be grouped under the umbrella of Design for Sustainable Behaviour, a field dedicated to the study of ways to make people think and do things that protect the environment (BHAMRA; LILLEY; TANG, 2011). Interventions are frequently used to promote sustainable behaviour, using different methods and having different levels of success (ABRAHAMSE et al., 2005; UITDENBOGERD et al., 2007). Previous research demonstrated examples of strategies to reduce water consumption. One shower equipped with LEDs made the quantity of water consumed progressively visible (KAPPEL; GRECHENIG, 2009) and a sink tap add-on allowed the visualization of water consumption and comparison with other users (ARROYO; BONANNI; SELKER, 2005). Another example added a method do visualise how long each housemate spend in the shower to foster competition (LASCHKE et al., 2011). On a comprehensive study, Froehlich et al. (2012) tested diverse visualisations of water consumption, documenting household activities in order to motivate savings in a domestic setting.

These examples illustrate a number of methods trying to persuade people to use less water. It is common to associate persuasion and rhetoric with psychologists, lawyers and marketers. However, designers and architects can also embed persuasion in the products, services or spaces that they are developing. Persuasion is often presented via electronic devices such as computers and smartphones, in a recent field named Persuasive Technology (FOGG, 2003; OINAS-KUKKONEN, 2013). Persuasive strategies can be used to promote a wide range of activities such as cycling and walking to work (ROSS et al., 2015), healthily eating (KAPTEIN et al., 2012) or electricity saving (OLIVEIRA; MITCHELL; MAY, 2016). One comprehensive list of persuasive principles can be found on The Design with Intent Method (LOCKTON; HARRISON; STANTON, 2010). They developed 101 cards (LOCKTON; HARRISON; STANTON, 2011) with patterns for influencing user behaviour through design in different categories, for example the architecture lens (influences user behaviour through the design of the environment), errorproofing (eliminating or reducing the chances of user making errors) and the cognitive lens (for situation where users make poor decisions, the design of the system can help indicating better choices). The cards contain enticing questions, descriptions and images of relevant examples of behaviour change strategies (Figure 2). Bhamra et al. (2011) describe a scale for classifying interventions that promote sustainable behaviour (Figure 1), which became known as the "Loughborough method" (NIEDDERER et al., 2014). This scale indicates the balance between power and control in the user-product relationship. On the first levels, the user is provided with choice and information in order to reflect upon resources consumption and behave in a sustainable way. With this principle the user has a relative freedom to perform otherwise. On the other side of the spectrum there are the eco-technological interventions and clever designs, when the product or service often acts automatically to save resources, without requiring much change in behaviours.

As can be seen from the literature, there are numerous design principles and patterns available to be implemented during behaviour change intervention projects. It suggests that a rigorous process of identifying the adequate ones that matches the behaviours in question should take place. The design of behaviour change interventions should

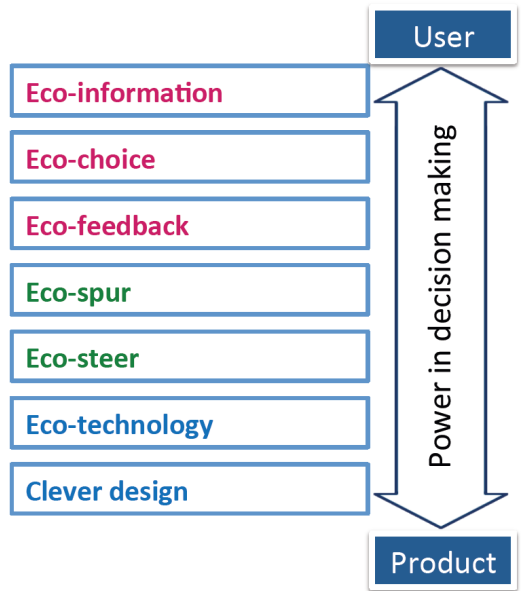

Figure 1 - Design for Sustainable Behaviour scale, adapted from (BHAMRA; LILLEY; TANG, 2011) 
consider a range of issues such as the potential for impact on the problem, the consequences, costs and complexity to implement (BOOTH, 1996). Furthermore, attempting to change people's behaviours should be made with care, given that having control over individuals and limiting user freedom via an intervention raises ethical concerns (PETTERSEN; BOKS, 2008).

\section{Methodology}

The current paper presents results from workshops that took place in a large university in Brazil. From a range of possible user research methods that could help the design for sustainable behaviour (DAAE; BOKS, 2015), workshops were chosen due to the possibility for combining learning and idea generation (GOODMAN; KUNIAVSKY; MOED, 2012). The participants were 35 students from Design (28) and Architecture (7). The content of the workshops introduced and explored Design for Sustainable Behaviour and Persuasive Technology to undergraduate students.

The activities involved two-day workshops for each of the courses. The first day of workshops consisted of the introduction of themes, divided in two sessions:

- Design for Sustainable Behaviour: How design can be used to purposely influence people's behaviours, and how design is used to minimise the damage to the environment, including examples of energy saving, active transport and water saving.

- Persuasive Technology: How computers, phones and technology in general can change what we think and do. This included examples of games and other applications to motivate behaviour change.

The second day of workshops included more hands-on activities, divided in three sessions:

- Classification of examples: Participants were asked to bring examples of their real life that fit into specific categories of behaviour change strategies. Students presented their selected examples to the group.

- Problem solving: One specific real-life problem was presented, and participants were asked to provide design solutions to change specific behaviours. All students were given the short briefing: to 'motivate people to save water'.

- Creativity workshop (Figure 3): Students were prompted to generate design solutions (Figure 4), which were presented orally at the end of the event. Participants from Architecture worked individually and from Design worked in small groups from four to six members.
The creativity workshop was instigated by the use of the Design with Intent Cards (LOCKTON; HARRISON; STANTON, 2010), translated to Portuguese, available online ${ }^{1}$. The content used during this workshop was produced exclusively to this purpose and kept freely available. For most of the material, this was the first time they were published in Portuguese, which benefited the students and broader community.

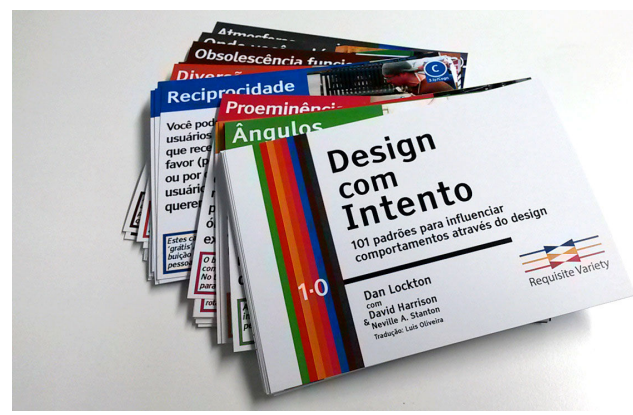

Figure 2 - Design with Intent Cards (LOCKTON; HARRISON; STANTON, 2010), translated to Portuguese

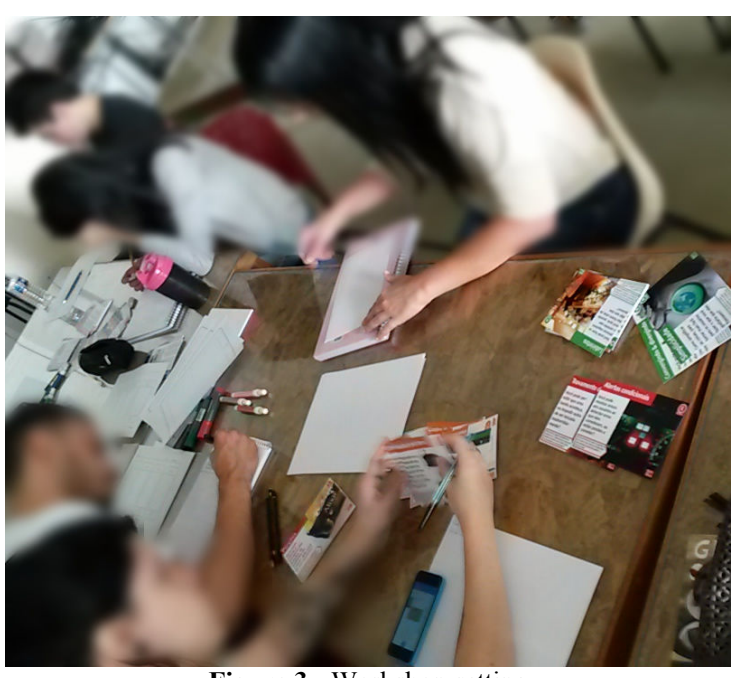

Figure 3 - Workshop setting

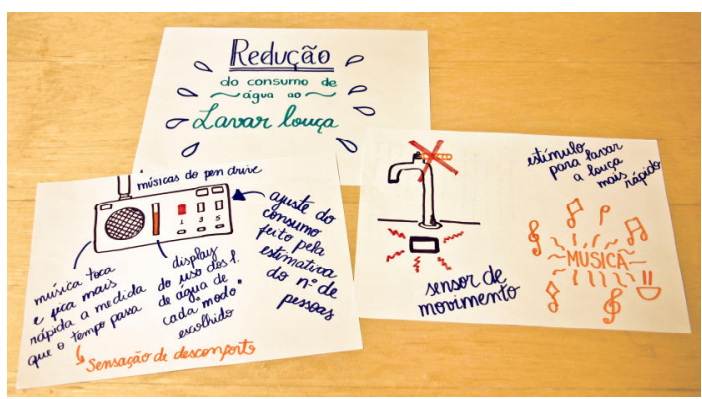

Figure 4 - Example of strategies from one of the groups

\footnotetext{
${ }^{1} \mathrm{http}: / /$ tecnologiapersuasiva.com.br/design-com-intento/
} 


\section{Results}

The outcomes from the creativity workshops comprised 14 proposals for reducing water consumption. The students presented these orally to the groups at the end of each series of workshops, when we took note of the details, commented on the strategies and asked questions. These suggested strategies were analysed and classified according to the Design with Intent Method (LOCKTON; HARRISON; STANTON, 2010) and the Design for Sustainable Behaviour model (BHAMRA; LILLEY; TANG, 2011). Table 4 below presents the classification of each design proposal presented. The first column presents the domain of water used chosen by the student or group. The second column contains a description of the project, as presented by the students. The third column describes the components of the intervention, in terms of hardware, software, product of system, to make the intervention possible to implement. The fourth and fifth columns contain the classification of the proposed interventions as per the Design with Intent method (LOCKTON; HARRISON; STANTON, 2010), separated by the individual strategies and the overarching lens. The last

Table 1 - Proposed domain of water use

\begin{tabular}{|l|c|}
\hline Domain & Number of projects \\
\hline Household & 4 \\
\hline Shower & 4 \\
\hline Taps & 4 \\
\hline Car washing & 1 \\
\hline Dish washing & 1 \\
\hline Washing machine & 1 \\
\hline Agribusiness and factories & 1 \\
\hline
\end{tabular}

Table 2 - Proposals classified by lens of the Design with Intent method

\begin{tabular}{|l|c|}
\hline Lens & Quantity \\
\hline Interaction & 9 \\
\hline Ludic & 9 \\
\hline Errorproofing & 6 \\
\hline Security & 4 \\
\hline Machiavellian & 2 \\
\hline Perceptual & 1 \\
\hline Cognitive & 1 \\
\hline
\end{tabular}

Table 3 - Proposals classified according to the Design for Sustainable Behaviour method

\begin{tabular}{|l|c|}
\hline DfSB method & Quantity \\
\hline Eco-feedback & 12 \\
\hline Eco-spur & 11 \\
\hline Eco-steer & 4 \\
\hline Eco-technical & 3 \\
\hline Clever design & 1 \\
\hline Eco-information & 1 \\
\hline
\end{tabular}

column also presents a classification of the suggested interventions, but this time using the Design for Sustainable Behaviour scale (BHAMRA; LILLEY; TANG, 2011). It is important to notice that the majority of the design proposals combined more than one domain and more than one strategy, resulting in 33 individual behaviour change techniques suggested.

The students presented an interesting range of projects to tackle the problem of water scarcity in Brazil. The domains of use varied from small, localised points of consumption such as taps or showers, to household-wide water use management (Table 1). Only one project proposed as target of the intervention large-scale scenarios such as the agribusiness and factories.

According to a classification of proposals into the different lens of the Design with Intent method (

Table 2), the two categories with most suggestions were 'Interaction' and 'Ludic'. Interaction interventions include some core patterns of human-computer interaction such as feedback, progress bars other representations of consumption. Students indicated the need to convey the use of water to users so they can realise the impact of their behaviour and hopefully act on that. Ludic elements are generally derived from games such as goal setting, challenges, targets, scores and rewards. Students suggested interventions where users would have a set target for water consumption. They could compete with peers and receive prizes for adequate behaviour. The next most frequent strategy proposed was errorproofing, indicating the need to avoid certain behaviours, which are considered 'errors'. These strategies usually "make it easier for users to work without making errors, or by making errors impossible in the first place" (LOCKTON; HARRISON; STANTON, 2010). Students proposed frequently the use of 'portions' of water, pre-defining the ideal volume to be used by each activity, therefore minimising the chances of waste. Four strategies included security to promote sustainable behaviours, making use of the Internet to share information about consumption where users control each other's behaviours. This control was proposed in different levels, from 'peerveillance', where users on the same level watch their peers, to 'sousveillance', where common people are given the ability to observe and monitor the behaviour of large consumers of water such as the agribusiness and factories. If these businesses know that they are being observed, they may be more cautious with the amount of water used to avoid negative public opinion. Two projects included Machiavellian elements to their intervention, both to degrade the performance in case of unsustainable behaviour. In one case the shower would get colder with time, and in the other the music will become faster to force the user to accelerate the washing up. Only one intervention included the Perceptual lens, suggesting a way to physically visualise the water dedicated to specific tasks and therefore increase awareness of usage. Likewise, only 
Table 4 - Proposed interventions for reducing water consumption classified according to the *Design with Intent and **Design for Sustainable Behaviour methods

\begin{tabular}{|c|c|c|c|c|c|c|}
\hline \# & Domain & Description & Components & Strategies* & Lenses* & Method*** \\
\hline 1 & Shower & $\begin{array}{l}\text { A display by the shower shows in real time the water and electricity } \\
\text { consumption via digits and graphs. Using GPS, it gathers the local tariffs to } \\
\text { calculate the cost per time. It sounds warnings if the user is taking too long }\end{array}$ & $\begin{array}{l}\text { Display } \\
\text { Speakers }\end{array}$ & $\begin{array}{l}\text { Real-time feedback } \\
\text { Conditional warning }\end{array}$ & $\begin{array}{l}\text { Interaction } \\
\text { Errorproofing }\end{array}$ & $\begin{array}{l}\text { Eco-feedback } \\
\text { Eco-spur }\end{array}$ \\
\hline 2 & Shower & $\begin{array}{l}\text { LED strip displaying minutes elapsed. After a set threshold the temperature } \\
\text { starts to decrease }\end{array}$ & LEDs, temperature control & $\begin{array}{l}\text { Progress bar } \\
\text { Portions } \\
\text { Degrading performance }\end{array}$ & $\begin{array}{l}\text { Interaction } \\
\text { Errorproofing } \\
\text { Machiavellian }\end{array}$ & $\begin{array}{l}\text { Eco-feedback } \\
\text { Eco-steer } \\
\text { Eco-spur }\end{array}$ \\
\hline 3 & Household & $\begin{array}{l}\text { Public policies define consumption targets. Users receive periodic } \\
\text { feedback. Prizes are given to those who met the targets }\end{array}$ & $\begin{array}{l}\text { Communications via water } \\
\text { bills }\end{array}$ & $\begin{array}{l}\text { Summary feedback } \\
\text { Challenges and targets } \\
\text { Rewards }\end{array}$ & $\begin{array}{l}\text { Interaction } \\
\text { Ludic } \\
\text { Ludic }\end{array}$ & $\begin{array}{l}\text { Eco-feedback } \\
\text { Eco-spur } \\
\text { Eco-technical }\end{array}$ \\
\hline 4 & $\begin{array}{l}\text { Agribusiness } \\
\text { and factories }\end{array}$ & $\begin{array}{l}\text { Expenditure of large consumers is shown to the public. Communities } \\
\text { became aware. Companies dialogue and communicate their campaigns to } \\
\text { reduce consumption }\end{array}$ & Web portal & Sousveillance & Security & Eco-feedback \\
\hline 5 & $\begin{array}{l}\text { Shower and } \\
\text { taps }\end{array}$ & $\begin{array}{l}\text { Water flow and time of use are pre-set according to activity, e.g. quantity } \\
\text { of dishes to wash, or a shower including washing the hair }\end{array}$ & Internal flow control & Portions & Errorproofing & Eco-steer \\
\hline 6 & Taps & $\begin{array}{l}\text { Users pre-set intended volume of water to use. Users can see the water } \\
\text { dedicated for the current task, and the tap counts down with a display. }\end{array}$ & Water tank, LED display & $\begin{array}{l}\text { parency } \\
\text { ins } \\
\text { ess bar }\end{array}$ & $\begin{array}{l}\text { Perceptual } \\
\text { Errorproofing } \\
\text { Interaction }\end{array}$ & $\begin{array}{l}\text { Eco-information } \\
\text { Eco-steer } \\
\text { Eco-feedback }\end{array}$ \\
\hline 7 & Taps & $\begin{array}{l}\text { Rainwater and used water is stored in tanks and re-distributed via dedicated } \\
\text { pipes }\end{array}$ & $\begin{array}{l}\text { Water tanks, distribution } \\
\text { pipes }\end{array}$ & - & - & Clever design \\
\hline 8 & Dish washing & $\begin{array}{l}\text { A sound system by the sink plays music and displays consumption on a } \\
\text { progress bar, and a sensor detects user proximity to prevent waste. Music } \\
\text { becomes faster after a certain time }\end{array}$ & $\begin{array}{l}\text { Sound system integrated } \\
\text { with tap, occupancy sensor }\end{array}$ & $\begin{array}{l}\text { Progress bar } \\
\text { Portions } \\
\text { Degrading performance }\end{array}$ & $\begin{array}{l}\text { Interaction } \\
\text { Errorproofing } \\
\text { Machiavellian }\end{array}$ & $\begin{array}{l}\text { Eco-feedback } \\
\text { Eco-spur } \\
\text { Eco-technical }\end{array}$ \\
\hline 9 & Car washing & $\begin{array}{l}\text { Hose pipe containing a sensor device that detects current usage and } \\
\text { cumulative water consumption. System shares participants' consumption } \\
\text { and they compete to win prizes }\end{array}$ & $\begin{array}{l}\text { Sensor, internet connection, } \\
\text { social network }\end{array}$ & $\begin{array}{l}\text { Peerveillance } \\
\text { Challenges and targets } \\
\text { Scores } \\
\text { Rewards }\end{array}$ & $\begin{array}{l}\text { Security } \\
\text { Ludic } \\
\text { Ludic } \\
\text { Ludic }\end{array}$ & $\begin{array}{l}\text { Eco-feedback } \\
\text { Eco-spur } \\
\text { Eco-spur } \\
\text { Eco-spur }\end{array}$ \\
\hline 10 & Household & $\begin{array}{l}\text { Domestic water use (divided per resident) is shared to foster competition. } \\
\text { Portal shows graphs with detailed consumption and gives advices on } \\
\text { saving water }\end{array}$ & Web portal, smart meters & $\begin{array}{l}\text { Summary feedback } \\
\text { Scores } \\
\text { Peerveillance }\end{array}$ & $\begin{array}{l}\text { Interaction } \\
\text { Ludic } \\
\text { Security }\end{array}$ & $\begin{array}{l}\text { Eco-feedback } \\
\text { Eco-spur } \\
\text { Eco-feedback }\end{array}$ \\
\hline 11 & $\begin{array}{l}\text { Washing } \\
\text { machine }\end{array}$ & $\begin{array}{l}\text { User indicates the appliance and cycle used and sees costs. System uses } \\
\text { GPS to collect the local tariff of electricity and water, and gives a report }\end{array}$ & Smartphone application & Summary feedback & Interaction & Eco-feedback \\
\hline 12 & $\begin{array}{l}\text { Shower and } \\
\text { taps }\end{array}$ & $\begin{array}{l}\text { The system has pre-defined volumes and flows dedicated to different } \\
\text { activities. An occupancy sensor stops the flow when the user leaves }\end{array}$ & $\begin{array}{l}\text { Water tanks, valves and } \\
\text { occupancy sensors }\end{array}$ & $\begin{array}{l}\text { Portions } \\
\text { Where you are }\end{array}$ & $\begin{array}{l}\text { Errorproofing } \\
\text { Security }\end{array}$ & $\begin{array}{l}\text { Eco-steer } \\
\text { Eco-technical }\end{array}$ \\
\hline 13 & Household & $\begin{array}{l}\text { Water company decodes bills and gives consumption on graphs and } \\
\text { compares with average of the area, by dwelling type. System gives tips on } \\
\text { how to save, and gives discounts for those saving the most }\end{array}$ & $\begin{array}{l}\text { Smartphone application for } \\
\text { feedback and comparison }\end{array}$ & $\begin{array}{l}\text { Summary feedback } \\
\text { Scores } \\
\text { Reward }\end{array}$ & $\begin{array}{l}\text { Interaction } \\
\text { Ludic } \\
\text { Ludic }\end{array}$ & $\begin{array}{l}\text { Eco-feedback } \\
\text { Eco-spur } \\
\text { Eco-spur }\end{array}$ \\
\hline 14 & Household & $\begin{array}{l}\text { Families use the system to visualise consumption down to each individual, } \\
\text { with specific interfaces for children. Graphs show consumption, and a } \\
\text { representation of trees blooming indicate the most efficient users }\end{array}$ & $\begin{array}{l}\text { Flow sensors } \\
\text { Smartphone application for } \\
\text { feedback }\end{array}$ & $\begin{array}{l}\text { Summary feedback } \\
\text { Scores } \\
\text { Emotional engagement }\end{array}$ & $\begin{array}{l}\text { Interaction } \\
\text { Ludic } \\
\text { Cognitive }\end{array}$ & $\begin{array}{l}\text { Eco-feedback } \\
\text { Eco-spur }\end{array}$ \\
\hline
\end{tabular}


one project suggested a Cognitive strategy, stimulating an emotional engagement between the user and the system. This group proposed that a representation of a tree would grow and bloom if the user saved water, motivating attachment to the virtual object. A large number of projects contained, indirectly, Architectural aspects, but not as a salient strategy, for example 'positioning', when screens and displays were positioned right at the location of consumption, for example in the in the shower or in front of the taps. Other common architectural strategy used in the background was the 'simplicity', when the system makes it easier for users to do something, for example when it calculates the local tariff to give the exact price of the current activity.

The interventions proposed by the students were classified in six of the seven levels on the Design for Sustainable Behaviour scale (Table 3). The vast majority fell under 'eco-feedback' and 'eco-spur'. With ecofeedback the design of the product or service informs users about what they are doing, and it helps them to make environmentally and socially responsible decisions via some sort of feedback. "The product provides tangible aural, visual, or tactile signs as reminders to inform users of resource use" (BHAMRA; LILLEY; TANG, 2011, p. 431). In this category are all the graphs, progress bars and representations of consumption proposed by the students. Eco-spur is defined as a design that inspires users via rewards to motivate good behaviour or penalties that punishes unsustainable usage. Examples of rewards include prizes and discounts, and a few punishments were also suggested by the students, such as sound warnings, music playing increasingly faster (and consequently unpleasant) or the water of a shower becoming gradually colder. Eco-steer was proposed four times via the provision of affordances and constraints embedded in the product. The suggested interventions defined the amount of water to be used in each session, therefore prescribing the adequate amount of water to be consumed. Three interventions proposed the use of eco-technical designs, when the product contains technological systems that persuade or control behaviours. Only one suggested system was classified under clever design, when the product or system automatically acts environmentally, without the awareness of the user, and without the need of behaviour change, and acting "purely through innovative product design" (BHAMRA; LILLEY; TANG, 2011, p. 431). The proposed design solution included the use of tanks to store rainwater and wastewater from taps and showers, which could be then reutilised. The only omission according to the Design for Sustainable Behaviour model was the 'ecochoice', when the product or system encourages consumers to reflect and to take responsibility of their behaviours via options and choices. The designs proposed by the students were generally 'scripted' (JELSMA; KNOT, 2002): users had certain specific sustainable behaviour to perform and no alternatives were suggested.

\section{Conclusion}

The workshops and the idea generation sessions reported here turned out to be remarkably fruitful in the attempt to develop interventions to promote sustainable behaviours. In the end there were 14 projects comprised of 33 strategies that could motivate people to use less water. These strategies could certainly contribute to the need to reduce water consumption in Brazil, a problem that became particularly emphasised in recent years.

A few limitations need to be considered as part of the conclusions presented here. Firstly, most of the students were not previously familiar with the definitions and classifications of strategies to change behaviour. The contents used during the workshops were delivered in a few hours and over the course of two days, therefore not enough time for immersing in the concepts for a thorough development process. The teaching of sustainable design is still in its infancy in Brazil, especially if compared with developed countries, where the design for sustainable behaviour is at the core of the curriculum and define the structure of courses. The activities performed in our twoday workshops in Brazil are generally part of semesterlong assignments in Norway (ZACHRISSON; BOKS, 2013). With more time, the proposed interventions could have had a higher variety of strategies, or apply to situations with higher impact on water consumption. From the 101 possible design strategies listed by Lockton (2011), only 15 were proposed by the students among the 32 strategies suggested. Also, most of the domains of water use were at an individual or local/residential level. Nevertheless, it was an interesting exercise to see the dedication of the students in producing and presenting their ideas in such a short time. Future work could expand these activities and embed them into the existing curricula. Also, it would be interesting to develop ideas to tackle problems in other domains, such as to reduce domestic electricity use, promote healthily behaviours or motivate sustainable and active transport methods instead of driving cars.

The workshops presented here were the first opportunity for some of the students to get in contact with a number of behaviour change techniques. The Design and Architecture students have an important role in society when creating the products, services, systems and spaces that can shape what we think and do. Once we know these tools, we are better positioned to use them, and prepared to develop interventions to target the complex sustainable challenges faced by humankind.

\section{Acknowledgements}

The authors would like to thank all participants in the workshops who contributed with great intervention ideas to reduce water consumption. This research was partially funded by the Research Office Santander Mobility Award, from Loughborough University, where the first author was 
working as a Research Associate at the time of the visit to Brazil. This award gives the opportunity for staff members to travel overseas, or to host overseas visitors at Loughborough, and is part of the Santander Universities scheme.

\section{References}

ABRAHAMSE, W.; STEG, L.; VLEK, C.; ROTHENGATTER, T. A review of intervention studies aimed at household energy conservation. Journal of Environmental Psychology, v. 25, n. 3, p. 273-291, set. 2005. Disponível em: $<$ http://linkinghub.elsevier.com/retrieve/pii/S027249440500054X >. Acesso em: 21 jul. 2011.

ARROYO, E.; BONANNI, L.; SELKER, T. Waterbot: exploring feedback and persuasive techniques at the sink. In: Proceedings of the SIGCHI conference on Human factors in computing systems, Anais...ACM, 2005.

ATTARI, S. Z.; DEKAY, M. L.; DAVIDSON, C. I.; DE BRUIN, W. B. Public perceptions of energy consumption and savings. Proceedings of the National Academy of Sciences, v. 107, n. 37, p. 16054-16059, 2010.

BERKHOLZ, P.; STAMMINGER, R.; WNUK, G.; OWENS, J.; BERNARDE, S. Manual dishwashing habits: an empirical analysis of UK consumers. International Journal of Consumer Studies, v. 34, n. 2, p. 235-242, 2010. Disponível em: $<$ http://dx.doi.org/10.1111/j.1470-6431.2009.00840.x>.

BHAMRA, T.; LILLEY, D.; TANG, T. Design for Sustainable Behaviour: Using Products to Change Consumer Behaviour. The Design Journal, v. 14, n. 4, p. 427-445, 1 dez. 2011. Disponível em:

$<$ http://www.tandfonline.com/doi/full/10.2752/175630611X1309 1688930453>.

BHAMRA, T.; LOFTHOUSE, V. Design for sustainability: a practical approach. Aldershot: Gower, 2007.

BOOTH, E. M. Starting with behavior: A participatory process for selecting target behaviors in environmental programs. [s.l: s.n.].

BROWN, B. J.; HANSON, M. E.; LIVERMAN, D. M.; MERIDETH, R. W. Global sustainability: Toward definition. Environmental Management, v. 11, n. 6, p. 713-719, nov. $1987 . \quad$ Disponível em: $<$ http://link.springer.com/10.1007/BF01867238>. Acesso em: 28 fev. 2017.

DAAE, J.; BOKS, C. A classification of user research methods for design for sustainable behaviour. Journal of Cleaner Production, v. 106, p. 680-689, nov. 2015. Disponível em: $<$ http://linkinghub.elsevier.com/retrieve/pii/S0959652614004120 >. Acesso em: 14 mar. 2017.

ELIZONDO, G. M.; LOFTHOUSE, V.; BHAMRA, T. An exploration of dishwashing habits in Anglo and Hispanic communities through the use of Cultural Probes. In: International Consumer Sciences Research Conference, Anais...2011.

FOGG, B. J. Persuasive technology: using computers to change what we think and do. USA: Morgan Kaufman: SF, CA, 2003.

FROEHLICH, J.; FINDLATER, L.; OSTERGREN, M.; RAMANATHAN, S.; PETERSON, J.; WRAGG, I.; LARSON, E.; FU, F.; BAI, M.; PATEL, S.; LANDAY, J. a. The design and evaluation of prototype eco-feedback displays for fixture-level water usage data. Proceedings of the SIGCHI Conference on Human Factors in Computing Systems, p. 2367-2376, 2012.
Disponível em: <http://doi.acm.org/10.1145/2207676.2208397>. FUSS, N.; BORNKESSEL, S.; MATTERN, T.; STAMMINGER, R. Are resource savings in manual dishwashing possible? Consumers applying Best Practice Tips. International Journal of Consumer Studies, v. 35, n. 2, p. 194-200, mar. 2011. Disponível em: $\quad<$ http://dx.doi.org/10.1111/j.14706431.2010.00972.x>.

GILL, Z. M.; TIERNEY, M. J.; PEGG, I. M.; ALLAN, N. Lowenergy dwellings: the contribution of behaviours to actual performance. Building Research \& Information, v. 38, n. 5, p. 491-508, 2010.

GOODMAN, E.; KUNIAVSKY, M.; MOED, A. Observing the user experience: a practitioner's guide to user research. 2 . ed. [s.1.] Morgan Kaufmann, 2012.

JELSMA, J.; KNOT, M. Designing environmentally efficient services; a "script" approach. The Journal of Sustainable Product Design, v. 2, n. 3/4, p. 119-130, 2002. Disponível em: $<$ http://dx.doi.org/10.1023/B:JSPD.0000031031.20974.1b>.

KAPPEL, K.; GRECHENIG, T. "Show-me": Water consumption at a glance to promote water conservation in the shower. In: Persuasive '09, Proceedings of the 4th International Conference on Persuasive Technology, New York, NY, USA. Anais... New York, NY, USA: ACM, 2009.

KAPTEIN, M.; DE RUYTER, B.; MARKOPOULOS, P.; AARTS, E. Adaptive Persuasive Systems: A Study of Tailored Persuasive Text. ACM Transactions on Interactive Intelligent Systems, v. 2, n. 2, p. 1-25, 2012. Disponível em: $<$ http://dl.acm.org/citation.cfm?doid=2209310.2209313>.

LASCHKE, M.; HASSENZAHL, M.; DIEFENBACH, S.; TIPPKÄMPER, M. With a little help from a friend: a shower calendar to save water. In: Proceedings of the 2011 annual conference extended abstracts on Human factors in computing systems, Anais...ACM, 2011.

LOCKTON, D.; HARRISON, D.; STANTON, N. A. The Design with Intent Method: A design tool for influencing user behaviour. Applied Ergonomics, v. 41, n. 3, p. 382-392, maio 2010. Disponível em: $<$ http://linkinghub.elsevier.com/retrieve/pii/S0003687009001136 $>$.

LOCKTON, D.; HARRISON, D.; STANTON, N. A. Design with Intent: 101 patterns for influencing behaviour through design. Disponível em: $<$ http://designwithintent.co.uk/introduction-to-the-design-withintent-toolkit/>. Acesso em: 2 mar. 2017.

NIEDDERER, K.; MACKRILL, J.; CLUNE, S.; LOCKTON, D.; LUDDEN, G.; MORRIS, A.; CAIN, R.; GARDINER, E.; GUTTERIDGE, R.; EVANS, M.; OTHERS. Creating Sustainable Innovation through Design for Behaviour Change: Full Project Report. [s.l: s.n.]. Disponível em: $<$ https://wlv.openrepository.com/wlv/handle/2436/336632>.

Acesso em: 27 fev. 2017.

NOBRE, C. A.; MARENGO, J. A.; SELUCHI, M. E.; CUARTAS, L. A.; ALVES, L. M. Some Characteristics and Impacts of the Drought and Water Crisis in Southeastern Brazil during 2014 and 2015. Journal of Water Resource and Protection, v. 8, n. 2, p. 252-262, 2016. Disponível em: $<$ http://www.scirp.org/journal/PaperDownload.aspx?DOI=10.423 6/jwarp.2016.82022>. Acesso em: 28 fev. 2017.

OINAS-KUKKONEN, H. A foundation for the study of behavior change support systems. Personal and Ubiquitous Computing, v. 17, n. 6, p. 1223-1235, 2013. Disponível em: $<$ http://link.springer.com/10.1007/s00779-012-0591-5>.

OLIVEIRA, L.; MAY, A.; MITCHELL, V.; COLEMAN, M.; KANE, T.; FIRTH, S. Pre-installation challenges: classifying 
barriers to the introduction of smart home technology. In: Proceedings of EnviroInfo and ICT for Sustainability 2015, Copenhagen, DK. Anais... Copenhagen, DK: Atlantis Press, 2015. Disponível em: <https://dspace.lboro.ac.uk/dspacejspui/handle/2134/19010>. Acesso em: 28 fev. 2016.

OLIVEIRA, L.; MITCHELL, V.; BADNI, K. Cooking behaviours: a user observation study to understand energy use and motivate savings. Work (Reading, Mass.), v. 41 Suppl 1, p. 2122-8, jan. 2012. Disponível em: $<$ https://doi.org/10.3233/WOR-2012-1016-2122>. Acesso em: 23 dez. 2015.

OLIVEIRA, L.; MITCHELL, V.; MAY, A. Reducing temporal tensions as a strategy to promote sustainable behaviours. Computers in Human Behavior, Disponível em: $<$ https://dspace.lboro.ac.uk/dspace-jspui/handle/2134/21131>, p. 303-315, 2016.

PEREIRA, A. F.; SOARES, S. R. Environmental parameters for ecodesign: a tool based on ecolabel programs and life cycle thinking. International Journal of Sustainable Design, v. 3, n. 1, p. 1, 2016. Disponível em: $<$ http://www.inderscience.com/link.php?id=78944>. Acesso em: 5 mar. 2017.

PETTERSEN, I. N.; BOKS, C. The ethics in balancing control and freedom when engineering solutions for sustainable behaviour. International Journal of Sustainable Engineering, v. 1, n. 4, p. 287-297, 2008.

ROSS, T.; BURRIS, A.; OLIVEIRA, L.; ARNOTT, B.; ARAUJO-SOARES, V. A feasibility study of the effect of phone-based feedback of other commuters' subjective experiences on driver intentions to change. Disponível em: $<$ https://dspace.lboro.ac.uk/dspace-jspui/handle/2134/19015>.

STAMMINGER, R. Modelling resource consumption for laundry and dish treatment in individual households for various consumer segments. Energy Efficiency, v. 4, n. 4, p. 559-569, 18 nov. 2011. Disponível em: <http://dx.doi.org/10.1007/s12053-0119114- $\mathrm{x}>$.

UITDENBOGERD, D.; EGMOND, C.; JONKERS, R.; KOK, G. Energy-related intervention success factors: a literature review. Proceedings of the eceee 2007 Summer Study: Saving Energy-Just Do It, v. 1, n. 4, p. 1853-1857, 2007.

ZACHRISSON, J.; BOKS, C. From teaching sustainable product design to teaching sustainable behaviour design. In: 2nd International Conference for Design Education Researchers, Oslo, Norway. Anais... Oslo, Norway: 2013. Disponível em: $<$ http://www.diva-

portal.org/smash/record.jsf?pid=diva2:730229>. Acesso em: 7 mar. 2017.

ZINK, K. J. Corporate sustainability as a challenge for comprehensive management. Heidelberg: Physica-Verlag HD, 2008. 